\title{
Impact of Green Pulp Banana and Flaxseed Flour on Pound Cake Quality
}

\author{
Marina Lisboa Silva, Luciana Gama de Mendonça, Rafael Audino Zambelli", \\ Ana Lídia Martins Magalhães, Cristiano Silva da Costa, Marcos Venânces De Souza Leão, \\ Rejane de Albuquerque Ribeiro de Sá Costa
}

Food Engineering Department, Federal University of Ceará, Fortaleza, Brazil

\section{Email address:}

Zambelli@ufc.br (R. A. Zambelli)

${ }^{*}$ Corresponding author

\section{To cite this article:}

Marina Lisboa Silva, Luciana Gama de Mendonça, Rafael Audino Zambelli, Ana Lídia Martins Magalhães, Cristiano Silva da Costa, Marcos Venânces De Souza Leão, Rejane de Albuquerque Ribeiro de Sá Costa. Impact of Green Pulp Banana and Flaxseed Flour on Pound Cake Quality. International Journal of Nutrition and Food Sciences. Vol. 6, No. 6, 2017, pp. 243-249. doi: 10.11648/j.ijnfs.20170606.15

Received: October 6, 2017; Accepted: October 25, 2017; Published: December 8, 2017

\begin{abstract}
The study investigated the combined effects of different levels of green pulp banana and flaxseed flour on the technological properties of pound cake. The effect of these ingredients was observed on the physical properties of the pound cakes (specific volume, symmetry, moisture and weight loss). The data were evaluated by response surface and the optimized formulation was evaluated, along with the control, through sensorial analysis, proximate composition and crumb porosity. A significant influence of the ingredients on the specific volume was observed, leading to their reduction. There was influence of green pulp banana on moisture and weight loss. In this way, the optimized formulation was established with $11.5 \%$ of green pulp banana and 5\% of flaxseed flour. The optimized formulation had a higher content of protein, ash and fat and lower carbohydrate content than the control formulation. In addition, there were no significant differences between the sensorial attributes evaluated, with texture exception.
\end{abstract}

Keywords: Formulation, Functional Food, Pound Cake, Protein Network

\section{Introduction}

Bakery products are consumed in large quantities on a daily base and have an important role in human nutrition. The addition of functional ingredients to bakery products has risen in popularity due to the ability to reduce risk of chronic diseases beyond basic nutritional functions [1]. Fruit, vegetable, cereal, legume, nut and seed are rich sources of dietary fiber, proteins, vitamins, minerals and other bioactive compounds that can be recovered and used as value added functional ingredients [2], within this context, green banana pulp and flaxseed have gained prominence.

The clear advantage presented by green banana flour includes a high total starch $(73.4 \%)$, resistant starch $(17.5 \%)$ and dietary fiber content $(\sim 14.5 \%)$ [3]. Due to the high content of these functional ingredients, regular consumption of green banana flour can be expected to confer beneficial health benefits for humans [4].
Studies have revealed the positive laxative effect of flaxseed, its role in reducing blood glucose and cholesterol level and, consequently, coronary and heart diseases. It is also believed to be effective in preventing breast, prostate and endometrial cancers, gastrointestinal disorders, diabetes, and osteoporosis [5], [6]. A variety of phytochemical compounds with antioxidant characteristics, including phenolic acids, lignans and flavonoids, are found in flaxseed [7] $\alpha$-linolenic acid and dietary fiber [8]. Phenolic acids, which exhibit antioxidant, anticarcinogenic and antimicrobial properties, are abundantly present in plants [9].

Therefore, the inclusion of these ingredients in a highconsumption food matrix is extremely important for the improvement of the nutritional quality of the population.

Cakes are baked products highly appreciated by the consumers worldwide, being characterized by a dense, tender 
crumb and sweet taste. Their quality mostly depends on ingredients used in the recipe, i.e. wheat flour, eggs, sugar, fat or oil and leavening agents, as well as on conditions prevailing during their preparation (e.g. mixing, baking). [9]. High quality cakes demonstrate attributes like superior volume, softness, even crumb structure, good sensory acceptability and anti-staling properties [10], and the addition of non-gluten-forming ingredients may compromise its quality.

In view of the foregoing, the study investigated the combined effects of different levels of green pulp banana and flaxseed flour on the technological properties of pound cake.

\section{Materials and Methods}

\subsection{Pound Cake Formulations}

Pound cake control formulation was prepared as in [11] from equal portions ( $300 \mathrm{~g}$ ) of wheat flour, margarine, sugar, milk and white egg, baking powder (5 g) and emulsifier $(2 \mathrm{~g})$. For cake preparation, sugar, margarine and emulsifier were initially creamed by mixing for $10 \mathrm{~min}$ at high speed (level three speed) in a LIEME-BP 06 (Lieme, Brazil). The eggs were then added to cream phase and mixed for $5 \mathrm{~min}$ at high speed. The wheat flour, baking powder, green pulp banana and flaxseed flour were then added and mixed for 5 min at low speed (level one speed) to obtain a uniform batter.

The batter was transferred to paper molds and placed in a electric oven (Electrolux, Brazil), at $175 \pm 2{ }^{\circ} \mathrm{C}$ for 30 minutes. After cooling to room temperature $\left(27^{\circ} \mathrm{C} / 1 \mathrm{~h}\right)$, the pound cakes were packaged in polyethylene plastic bags. Cake samples were stored at room temperature for quality analysis.

The levels of green banana pulp and flaxseed flour in pound cake formulations were established according to the Central Composite Rotational Design (CCRD) matrix shown in Table 1.

Table 1. Runs of the experiment and the amount of the green banana pulp and flaxseed flour used in the study.

\begin{tabular}{lll}
\hline Runs & Green Banana Pulp (\%) $\mathbf{X}_{\mathbf{1}}$ & Flaxseed Flour (\%) $\mathbf{X}_{\mathbf{2}}$ \\
\hline 1 & $10.0(-1)$ & $5.0(-1)$ \\
2 & $10.0(-1)$ & $15.0(+1)$ \\
3 & $30.0(+1)$ & $5.0(-1)$ \\
4 & $30.0(+1)$ & $15.0(+1)$ \\
5 & $5.84(-1.41)$ & $10.0(0)$ \\
6 & $34.14(+1.41)$ & $10.0(0)$ \\
7 & $20.0(0)$ & $2.92(-1,41)$ \\
8 & $20.0(0)$ & $17.07(+1,41)$ \\
9 & $20.0(0)$ & $10.0(0)$ \\
10 & $20.0(0)$ & $10.0(0)$ \\
11 & $20.0(0)$ & $10.0(0)$ \\
\hline
\end{tabular}

Green banana pulp was processed according to methodology applied by [12] with modifications; the green bananas were purchased at local stores in Fortaleza, Brazil and conducted to the laboratory. They were washed in running water with sponge aid, and then placed in aqueous solution of sodium hypochlorite (1:100 water: hypochlorite) to promote the bananas sanitization.

\subsection{Technological Characteristics of the Pound Cakes}

The specific volume, symmetry and uniformity indices were determined 1 day after the pound cakes were prepared. The moisture content was evaluated in fresh pound cake.

The specific volume was calculated as the ratio of apparent volume to weight. Apparent volume $(\mathrm{mL})$ was measured by seed displacement, according to AACC method 10-05.01 [13], and weight (g) was determined using a Toledo AR41 semi-analytical balance (Toledo, Switzerland). Cake symmetry and uniformity indices were calculated according to AACC method 10-90.01 [13].

\subsection{Image Analysis}

\section{Pound cake crumb image analysis}

The pound cake was sliced transversely with a slicing machine. The images were captured using a color camera (NIKON P610, Nikon Inc., Japan) with a resolution of 4272 $\times 2848$ pixels. The camera was located at $20 \mathrm{~cm}$ overhead on the sample platform to obtain the best image of the samples of bread slices throughout the experiment. The samples were illuminated with two $36 \mathrm{~W}$ fluorescent lights (model: T8 G13, Phillips, Brazil) and enclosed in a black cardboard box with a door [14]. The inside wall of the box was concealed with black paper to reduce the reflectance and the roof was covered with white paper to enhance light scattering and reduce the shadow [15]. The sliced bread samples were positioned on a black background to provide higher contrast between the background and the sample. The camera was connected to a computer, which contained remote shooting software Nikon Wireless Mobile Utility (WMU) (version 1.5.0, Nikon INC, Japan) through which the digital images were acquired.

The digital images were treated using Image J software (National Institute of Health, Bethesda, MD, USA). The image was split in color channels, the contrast was enhanced and, finally, the image was binarized after applying a greyscale threshold. This was performed with the aim of dividing images into regions of cells and surrounding cell wall material. The analysis was performed on a slice area of $15 \times 17 \mathrm{~mm}$. Porosity measurements were measured in triplicate (number of cells and circularity) [16].

Scanning electron microscopy (SEM)

The surface of pound cake was observed using a Inspect S50 Scanning Electron Microscope (at low energy of $10 \mathrm{kV}$ ). The samples were deposited on carbon tapes and coated with gold, using vapor deposition techniques. The surface was scanned using a magnification between 5.000 and $40.000 \times$.

\subsection{Statistical Analysis}

CCRD was performed to obtain a second-order model (Eq. 1) to predict the pound cake quality in function of green pulp banana and flaxseed flour of the pound cake formulations.

$$
y=\beta_{0}+\sum_{i<j} \beta_{i j} x_{i} x_{j}+\sum_{j} \beta_{j j} x_{j}^{2}+\varepsilon
$$

where $\mathrm{y}$ is the predicted response (pound cake quality), $\beta_{0}$ is 
the global mean, $\beta_{\mathrm{j}}$ is the linear coefficient, $\beta_{\mathrm{ij}}$ is the coefficient of interaction, $\beta_{\mathrm{jj}}$ is the quadratic coefficient, $\varepsilon$ is the error of the model, and $x_{i}$ and $x_{j}$ are the coded values of the independent variables.

The experimental data were analyzed using Statistica software, version 8.0 (Statsoft, Inc., Tulsa, OK, USA). Analysis of variance (ANOVA) tables were generated and the effect and regression coefficients of individual linear, quadratic and interaction terms were determined. The significances of all terms were judged statistically according to the $p$-value, which was set at a $5 \%$ significance level. The quality-of-fit of the model equation was expressed by the coefficient of determination $\left(\mathrm{R}^{2}\right)$, and its statistical significance was determined using the F-test. For validation of the statistical results, the observed values of dough and bread quality variables were compared with the predicted values obtained by the experimental models. The independent variables optimized were $\mathrm{X}_{1}$ (Green pulp banana), $X_{2}$ (Flaxseed flour) for dependent response $Y_{1}$ (Specific Volume), $\mathrm{Y}_{2}$ (Symmetry), $\mathrm{Y}_{3}$ (Uniformity), and $\mathrm{Y}_{4}$ (Bake Loss) and $\mathrm{Y}_{5}$ (Moisture). The complete design consisted of 11 combinations performed in standard order (Table 1).

For the control and optimized formulation, the analysis of centesimal composition (moisture, ash, protein, fat and carbohydrate content) and sensorial analysis were performed.

The determinations of values of moisture (method $n^{\circ} 44-$ 15.02), protein $\left(\mathrm{n}^{\circ} 46-09.01\right)$, fat $(30-25.01)$, ash $\left(\mathrm{n}^{\circ} 08\right.$ 01.01) and the carbohydrate content was determined by difference [13].

Sensory analysis was performed by 64 non-trained panelists, who received about $25 \mathrm{~g}$ of pound cake, previously weighed in analytical balance and were presented in plastic cups randomly encoded.

The statistics used in these analyzes were ANOVA and Tukey mean test $(\mathrm{p}<0.05)$.

\section{Results \& Discussion}

Table 2 presents the physical quality parameters of pound cakes with different levels of green pulp banana and flaxseed flour. The increased degree of green pulp and flaxseed flour resulted in a lower specific volume and symmetry. Cakes with higher moisture and bake loss values were obtained with the lowest addition of the ingredients, associated with the higher water absorption capacity of the flaxseed flour and resistance starch presents in green pulp banana. In the same way, the cakes added with $5.84 \%$ of green banana pulp and $10.0 \%$ of flaxseed flour presented higher specific volume $\left(1.95 \mathrm{~cm}^{3} / \mathrm{g}\right)$ and symmetry $(3.20 \mathrm{~cm})$.

Table 2. Physical quality parameters of pound cakes added of different levels of green pulp banana and flaxseed flour.

\begin{tabular}{|c|c|c|c|c|}
\hline Runs & Specific Volume $\left(\mathrm{cm}^{3} / \mathrm{g}\right)$ & Symmetry (cm) & Moisture (\%) & Bake Loss (\%) \\
\hline 1 & $1.73^{b} \pm 0.03$ & $2.36^{\mathrm{b}} \pm 0.10$ & $39.46^{\mathrm{d}} \pm 0.10$ & $12.57^{\mathrm{a}} \pm 0.08$ \\
\hline 2 & $1.64^{\mathrm{c}} \pm 0.02$ & $1.90^{c} \pm 0.10$ & $39.18^{\mathrm{de}^{2}} \pm 0.18$ & $9.20^{c} \pm 0.07$ \\
\hline 3 & $1.40^{\mathrm{df}} \pm 0.02$ & $1.40^{\mathrm{ef}} \pm 0.10$ & $41.93^{\mathrm{a}} \pm 0.70$ & $4.57^{\mathrm{fg}} \pm 0.03$ \\
\hline 4 & $1.27^{\mathrm{e}} \pm 0.02$ & $1.00^{\mathrm{d}} \pm 0.10$ & $40.63^{\mathrm{b}} \pm 0.04$ & $3.12^{\mathrm{e}} \pm 0.04$ \\
\hline 5 & $1.95^{\mathrm{a}} \pm 0.02$ & $3.20^{\mathrm{a}} \pm 0.10$ & $38.07^{\mathrm{cf}} \pm 0.03$ & $11.14^{\mathrm{b}} \pm 0.03$ \\
\hline 6 & $1.27^{\mathrm{e}} \pm 0.03$ & $1.23^{\mathrm{df}} \pm 0.05$ & $40.49^{b} \pm 0.43$ & $2.78^{\mathrm{g}} \pm 0.02$ \\
\hline 7 & $1.44^{\mathrm{d}} \pm 0.02$ & $1.50^{\mathrm{e}} \pm 0.10$ & $39.28^{\mathrm{de}} \pm 0.04$ & $8.18^{\mathrm{d}} \pm 0.03$ \\
\hline 9 & $1.37^{\mathrm{f}} \pm 0.03$ & $1.36^{\mathrm{df}} \pm 0.05$ & $38.74^{\mathrm{def}} \pm 0.35$ & $6.17^{\mathrm{h}} \pm 0.02$ \\
\hline 10 & $1.36^{\mathrm{f}} \pm 0.02$ & $1.33^{\mathrm{df}} \pm 0.05$ & $38.68^{\mathrm{ef}} \pm 0.08$ & $6.18^{\mathrm{h}} \pm 0.03$ \\
\hline 11 & $1.36^{\mathrm{f}} \pm 0.02$ & $1.30^{\mathrm{df}} \pm 0.10$ & $37.55^{\mathrm{c}} \pm 0.02$ & $6.21^{\mathrm{h}} \pm 0.06$ \\
\hline
\end{tabular}

${ }^{1}$ Superscript Lowercase letters in the same column do not differ significantly by Tukey test $(\mathrm{p} \leq 0.05)$; $\pm=$ Standard deviation.

The pound cake symmetry variation $(1.00 \mathrm{~cm}$ to $3.20 \mathrm{~cm})$ shows that the cake center was slightly higher than its extremities. In this way, the greater the symmetry, the greater the elevation of cake center in relation to its extremities, and consequently, the greater is the specific volume of pound cake. According to [17], its characteristic of pound cakes due to the opening that occurs in the top center of the cake and [18] found a reduction in the cake volume and symmetry of added Rubus coreanus powder.

Specific Volume can be related to the amount of air incorporated in the batter during the mixing process [19] your reduction with increased levels of green pulp banana and flaxseed flour signaling that damage to the gluten network may have occurred, making it difficult to trap air. [20] mentioned that air incorporation depends on beater speed, viscosity and surface tension, among others and included that "the efficiency of air retention depends on the speed at which air bubbles rise out of the batter". It is believed that the inclusion of green banana pulp and flaxseed flour may have caused the increase of dough viscosity.

[21] found no significant differences in total moisture of cakes added with whey protein. In this study, it was verified that flaxseed flour promoted the reduction of total cake moisture. This result was expected since the product is in the form of flour.

Table 3 presents the mathematical models of dependent variables in function of green pulp banana and flaxseed flour levels.

The effects of independent variables on the physical quality parameters of pound cakes were studied using CCRD. Mathematical models were developed to relate independent variables on the pound cake quality. Table 3 shows the coefficients of the variables in the models and their contributions to the model's variation, to the judge the 
adequacy of the models were used $\mathrm{R}^{2}$.

Table 3. Codec models for physical quality parameters as a function of the green pulp banana and flaxseed flour level (the coded values of the independent variables must be used).

\begin{tabular}{lll}
\hline Dependent Variable & Model & $\mathbf{R}^{2}$ \\
\hline Specific Volume $\left(\mathrm{cm}^{3} / \mathrm{g}\right)$ & $\mathrm{Y}=1.36-0.20 \mathrm{X}_{1}+0.12 \mathrm{X}_{1}^{2}-0.04 \mathrm{X}_{2}$ & 0.9685 \\
Symmetry (cm) & $\mathrm{Y}=1.29-0.58 \mathrm{X}_{1}+0.42 \mathrm{X}_{1}^{2}-0.14 \mathrm{X}_{2}$ & 0.9332 \\
Moisture (\%) & $\mathrm{Y}=38.80+0.91 \mathrm{X}_{1}+0.81 \mathrm{X}_{1}^{2}-0.40 \mathrm{X}_{2}+0.52 \mathrm{X}_{2}^{2}$ & 0.8829 \\
Bake Loss (\%) & $\mathrm{Y}=6.19-3.26 \mathrm{X}_{1}+0.63 \mathrm{X}_{1}^{2}-1.43 \mathrm{X}_{2}+0.58 \mathrm{X}_{1} \mathrm{X}_{2}$ & 0.9616 \\
\hline
\end{tabular}

$\mathrm{X}_{1}=$ Pulp green banana and $\mathrm{X}_{2}=$ Flaxseed flour

All dependent variables presented satisfactory $\mathrm{R}^{2}$ for a good fit of the mathematical models as a function of the green pulp banana and flaxseed flour levels.

Statistical analysis of the results showed that the independent variables have a significant influence $(\mathrm{p}<0.05)$ on physical quality parameters, so response surfaces (Figure 1) could be obtained.

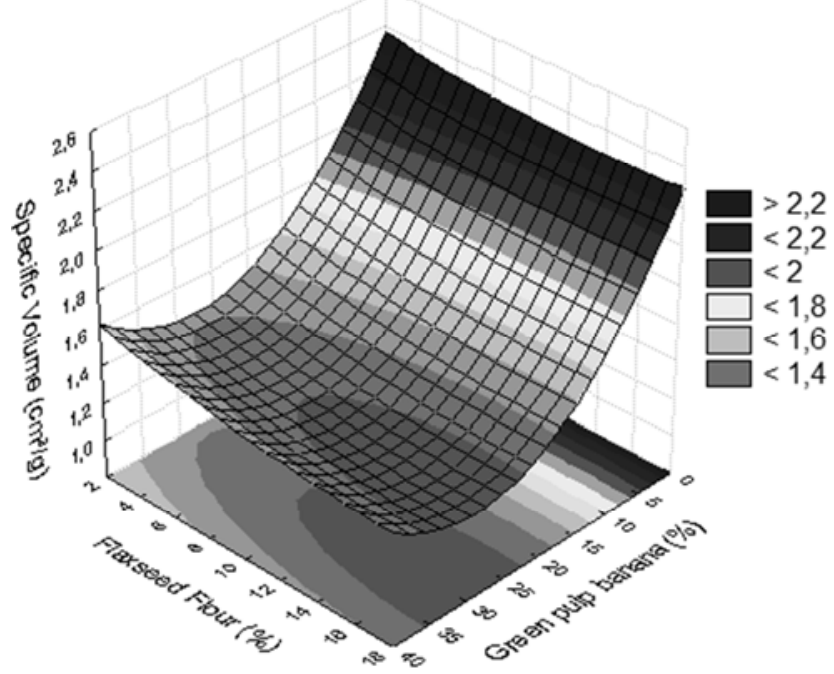

(A)

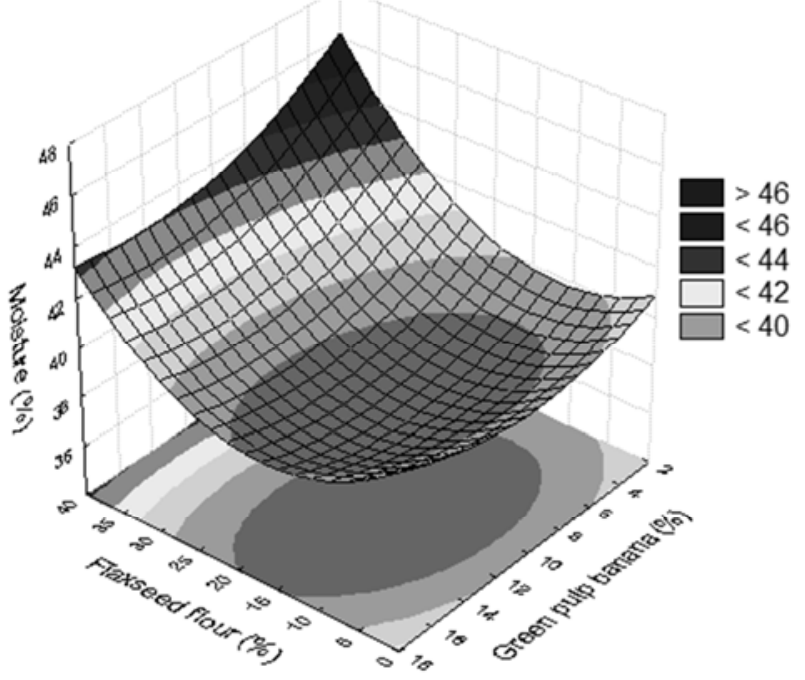

(B)

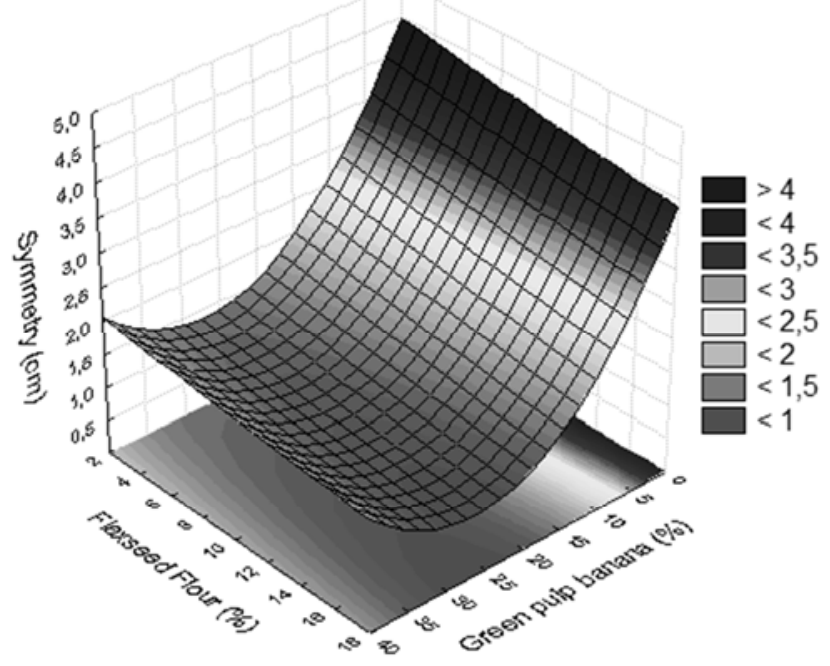

(C)

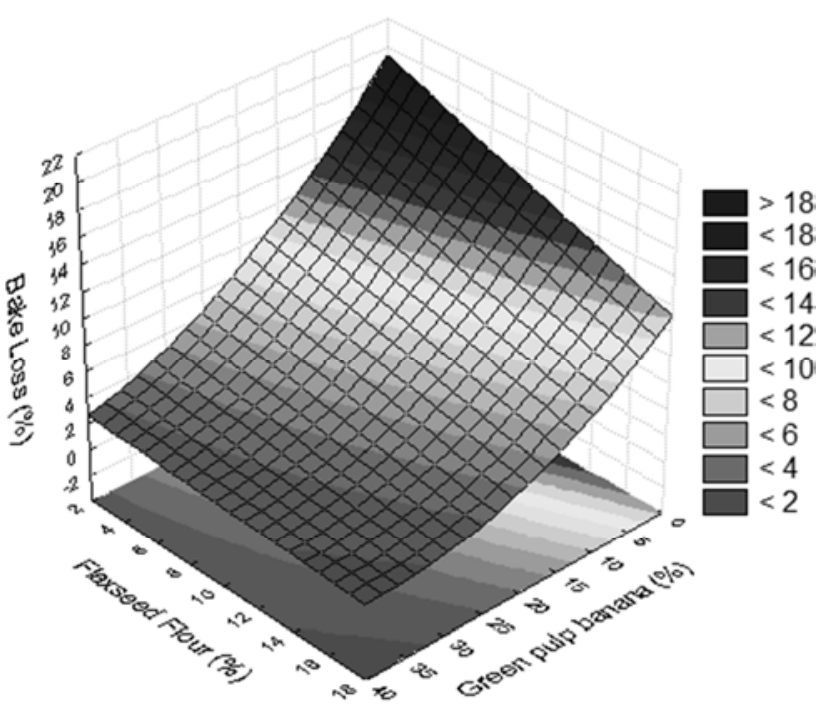

(D)

Figure 1. Response surface plot of physical quality parameters of pound cake as a function of green banana pulp and flaxseed flour. (A) - Specific Volume; (B) - Moisture; (C) - Symmetry and (D) - Bake Loss.

According to the response surface figure (Figure 1a), there is a direct correlation between the level of green pulp banana and specific volume of pound cake. The incorporation above $10 \%$ promoted reduction of the specific volume to values 
lower than $2.00 \mathrm{~cm}^{3} / \mathrm{g}$. However, below this value, the flaxseed flour may be added in levels of 1 to $18 \%$ without causing a significant reduction in the volume of the pound cake. This result can be related with the dietary fiber content of green pulp banana. According [22], this content can be as high as $50 \%$ (based on dry basis), while the hemicelluloses is $\sim 20 \%$ [23].

During breadmaking, different ingredients are used to ensure the development of a continuous protein network that is essential for bread quality. The added bioactive ingredients may or may not promote the protein cross-links. Appropriate cross-links between wheat proteins, fiber polysaccharides, and phenolic antioxidants could be the most critical factor for bread dough enhanced with dietary fiber and phenolic antioxidants [24].

[25], [26] and [27] report the presence of fiber with the reduction of bread volume, dilution and breakage of the gluten network, compromising the quality of bakery products and [28] related reduction in cake volume due the chickpea flour inclusion.

Pound cake moisture ranged from 41.93 to $37.55 \%$ (Figure 1B) and it was affected significantly by green banana pulp and flaxseed flour. The increase of green banana pulp concentration resulted in higher moisture content. This result can be associated to higher moisture content of this raw material. On the other hand, flaxseed flour contributed to the reduction of moisture content due to its flour form.

[11] found the moisture content ranging between 25.0 and $33.0 \%$ and [29] values close to $26 \%$ of moisture.

Therefore, it was verified through correlation analysis that the cake moisture did not present significant correlation (0.26) with the specific volume, however, there was significance for green pulp banana (0.62).

Moisture content in foods is indicative of quality, and moistness is one of the desirable sensory characteristics in baked products, as it is usually related to a soft product [30]. In this way, the inclusion of green banana pulp can bring these benefits to the pound cake.

The initial and final data on cake pound weight are available. The results are reported in Figure 1D. The pound cake water content is the main responsible for weight loss. From the comparison of the different formulations of pound cake it is possible to observe that the greater levels of green banana pulp and flaxseed flour addition lower was the pound cake weight loss.

This result suggests that the inclusion of the green banana pulp and flaxseed flour presented water absorption capacity, probably because of the dietary fiber content. [31] says that the fiber content having a much higher water absorption capacity than intact starch, could diminish the free water content.

The green pulp banana presented higher negative correlation with pound cake bake loss $(-0.88)$, while the flaxseed flour presented lower negative correlation $(-0.32)$, however were significant.

Specific Volume relationship with the baking loss has also been studied. The pound cakes that presented higher baking loss also presented higher specific volume. [32] related the influence of the water vaporization process during baking with specific volume. The presence of many water porous on the dough increase the volume.

The pound cake symmetry was affected significantly by green pulp banana and flaxseed flour. At high levels of addition of the ingredients an increase in positive symmetry values was observed.

Symmetry indicates the differences in height between the central zone and the lateral zone. Thus, a high symmetry suggests that cakes mainly rise in their central part, while a negative symmetry indicates that cake volume falls down at the end of the baking process. Hence, symmetry gives an idea about gas retention in the final baking phase. In both cases the incorporation of chickpea flour reduced their symmetry [33].

Thus, after the evaluation of the results obtained from the response surface, the inclusion of $11.5 \%$ of green banana pulp and correlated with $5 \%$ of flaxseed flour were considered the optimized values.

Sensory evaluation of the pound cakes was performed by 64 assessors. The averages of the tallied responses of the assessors to the appearance, color, flavor and texture of the pound cake are shown in the Table 4.

Table 4. Average of the scores (responses) of the assessors $(n=64)$ to the sensorial attributes of the pound cakes, proximate composition and porosity.

\begin{tabular}{lll}
\hline Sensorial Attributes & $\begin{array}{l}\text { Control } \\
\text { Formulation }\end{array}$ & $\begin{array}{l}\text { Optimized } \\
\text { Formulation }\end{array}$ \\
\hline Appearance & $8.35^{\mathrm{a}} \pm 0.33$ & $7.91^{\mathrm{a}} \pm 0.17$ \\
Colour & $7.75^{\mathrm{a}} \pm 0.32$ & $7.94^{\mathrm{a}} \pm 0.15$ \\
Flavour & $7.71^{\mathrm{a}} \pm 0.27$ & $8.01^{\mathrm{a}} \pm 0.22$ \\
Texture & $8.30^{\mathrm{a}} \pm 0.21$ & $7.90^{\mathrm{b}} \pm 0.19$ \\
Proximate Composition & & \\
Moisture $(\%)$ & $33.85^{\mathrm{b}} \pm 0.17$ & $38.69^{\mathrm{a}} \pm 0.14$ \\
Ash $(\%)$ & $1.15^{\mathrm{b}} \pm 0.03$ & $2.34^{\mathrm{a}} \pm 0.02$ \\
Protein $(\%)$ & $5.85^{\mathrm{b}} \pm 0.10$ & $6.94^{\mathrm{a}} \pm 0.06$ \\
Fat $(\%)$ & $3.94^{\mathrm{b}} \pm 0.12$ & $4.21^{\mathrm{a}} \pm 0.04$ \\
Carbohydrate $(\%)$ & $55.21^{\mathrm{a}} \pm 0.09$ & $47.91^{\mathrm{b}} \pm 0.08$ \\
Porosity & & \\
Number of Cells & $1,495^{\mathrm{a}} \pm 28$ & $1,058^{\mathrm{a}} \pm 34$ \\
Cell's Circularity & $0.885^{\mathrm{a}} \pm 0.04$ & $0.793^{\mathrm{a}} \pm 0.05$ \\
\hline
\end{tabular}

${ }^{1}$ Superscript lowercase letters in the same row do not differ significantly by Tukey test $(\mathrm{p} \leq 0.05) ; \pm=$ Standard deviation.

The control pound cake had a highest average score for texture (score $=8.30$, like moderately). For the other attributes, no significant differences were observed between the control pound cake and the optimized pound cake added of green pulp banana and flaxseed flour.

According to the one-way ANOVA, significant differences $(p<0.05)$ occurred between the proximate compositions of the pound cakes. According to the Tukey's post-hoc test all parameters of proximate composition presented significant differences.

The addition of green pulp banana and flaxseed flour 
provides pound cakes with higher protein, ashes and fats content, and reduced the carbohydrates when compared to the control pound cake.

[15] identified reduction in sensory attributes with egg substitution by emulsifiers and whey protein, a similar result was obtained by [22] and [34]. [35] studied the whole chia flour incorporation in pound cakes and found increase in protein, ash and fat content and reduction in carbohydrate content.

The crumb porosity of optimized pound cake was lower than the control pound cake. There was a significant reduction in the number of cells and their circularity. This can be explained by a reduction of gas retention in the batter during mixing when green pulp banana and flaxseed flour were used.

During baking, the batter viscosity decreases, and, as a result, air bubbles move and are lost from the batter at an increasing rate [36]. At this point, the batter viscosity should still be sufficient to minimize gas cell coalescence, disproportionation, and bubble rise and to keep the dense starch granules suspended before gelatinization occurs [37]. At this stage of baking, the gas cells expand because of the release of carbon dioxide from the leavening agent [38]. The inclusion of green pulp banana and flaxseed flour have impaired the formation of bubbles during the batter mixing stage, as well as promote damage to the gluten network by the presence of fibers and minerals, as can be seen in Figure 2.

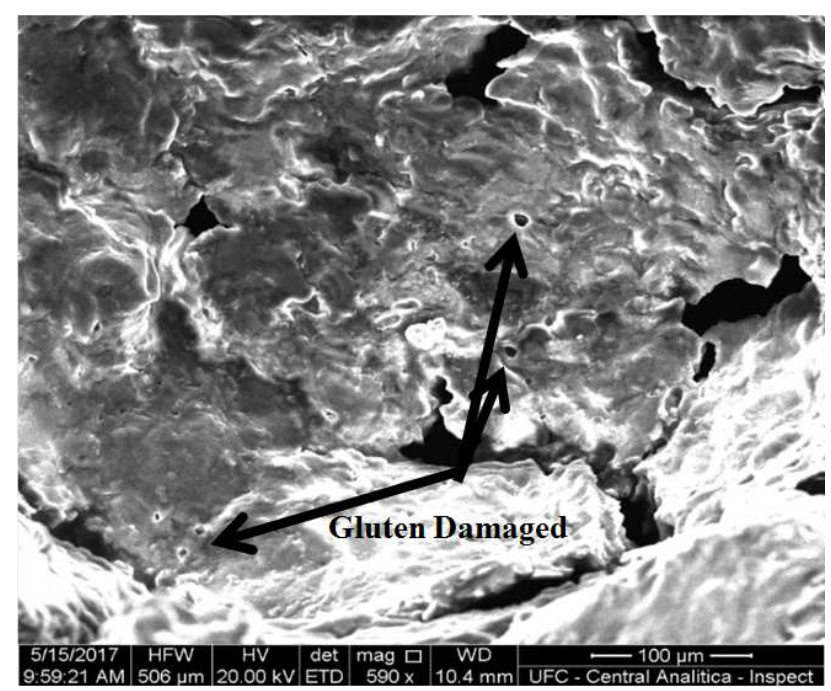

Figure 2. Scanning electron microscopy of optimized pound cake.

\section{Conclusions}

Pound cake physical properties decrease of the green pulp banana and flaxseed flour incorporation. However, the addition in levels of $11.5 \%$ and $5 \%$, respectively produce good volume, symmetry and low weight loss in the pound cakes. Moreover, the sensory attributes are not impaired by the inclusion of these ingredients.

There was an improvement in the nutritional quality of pound cakes, when compared to the control formulation, through the increase of the proteins, ashes and fats content, besides the reduction of the carbohydrate content.

\section{References}

[1] S. Eswaran, J. Muir, W. D. "Chey Fiber and functional gastrointestinal disorders." The American Journal of Gastroenterology, 108 (2013), pp. 718-727.

[2] P. B. Helkar, A. Sahoo, N. PatilReview: "Food industry byproducts used as a functional food ingredientes." International Journal of Waste Resources, 6 (2016), p. 248.

[3] E. Juarez-Garcia, E. Agama-Acevedo, S. G. Sayago-Ayerdi, S. L. Rodriguez-Ambriz, L. A. Bello-Perez "Composition, digestibility and application in breadmaking of banana flour." Plant Foods for Human Nutrition, 61 (2006), pp. 131-137.

[4] S. L. Rodriguez-Ambriz, J. J. Islas-Hernández, E. AgamaAcevedo, J. Tovar, L. A. Bello-Pérez "Characterization of a fiber-rich powder prepared by liquefaction of unripe banana flour." Food Chemistry, 107 (2008), pp. 1515-1521.

[5] S. Fukumitsu, K. Aida, H. Shimizu, K. Toyoda. "Flaxseed lignan lowers blood cholesterol and decreases liver disease risk factors in moderately hypercholesterolemic men." Nutr. Res., 30 (2010), pp. 441-446.

[6] S. Villeneuve, L.-P. Des Marchais, V. Gauvreau, S. Mercier, C. B. Do, Y. Arcand. "Effect of flaxseed processing on engineering properties and fatty acids profiles of pasta". Food Bioprod. Process., 91 (2013), pp. 183-191.

[7] L. B. Pouzo, A. M. Descalzo, N. E. Zaritzky, L. Rossetti, E. Pavan. "Antioxidant status, lipid and color stability of aged beef from grazing steers supplemented with corn grain and increasing levels of flaxseed." Meat Sci., 111 (2016), pp. 1-8.

[8] Hall III, C., Tulbek, M. C., \& Xu, Y. (2006). Flaxseed. In: Taylor, S. (Ed.), Advances in Food and Nutrition Research, 51, $1-97$.

[9] B. D. Oomah, E. O. Kenaschuk, G. Mazza "Phenolic acids in flaxseed.” J. Agric. food Chem., 43 (1995), pp. 2016-2019.

[10] A. Paraskevopoulou, S. Donsouzi, C. V. Nikiforidis, V. Kiosseoglou. "Quality characteristics of egg-reduced pound cakes following WPI and emulsifier incorporation." Food Research International, Volume 69, March 2015, Pages 72-79.

[11] M. Gomez, F. Ronda, P. A. Caballero, C. A. Blanco, C. M. Rosell "Functionality of different hydrocolloids on the quality and shelf life of yellow layer cakes." Food Hydrocolloids, 2 (2007), pp. 167-173.

[12] A. Luyts, E. Wilderjans, I. VanHaesendonck, K. Brijs, C. M. Courtin, J. A. Delcour "Relative importance of moisture migration and amylopectin retrogradation for pound cake crumb firming." Food Chemistry, 141 (4) (2013), pp. 3960-3966.

[13] VALLE, H. F.; CAMARGO, M. Yes, nós temos banana. São Paulo: Editora Senac, 2003.

[14] AACC- Approved methods of American association of cereal chemists. American Association of Cereal Chemists, St. Paul, USA (2010).

[15] Al-Rahbi, S., Manickavasagan, A., Al-Yahyai, R., Khriji, L., $\&$ Alahakoon, P. Detec-tinsurface cracks on dates using color imaging technique. Food Sci. Technol. Res., 19 (4) (2013), pp. 795-804. 
[16] Al-Ohali, Y. I. Computer vision based date fruit grading system: design and implementation. J. King Saud Univ. Comput. Inf. Sci., 23 (1) (2011), pp. 29-36.

[17] Martínez, M. M., Román, L., and Gómez, M. "Implications of Hydration Depletion in the Vitro Starch Digestibility of White Bread Crumb and Crust." Food Chemistry 239 (1) (2018), pp. 295-303.

[18] E. L. Almeida, A. L. Marangoni, C. J. Steel. "Starches from non - conventional sources to improve the technological characteristics of pound cake." Ciência Rural, Santa Maria, v. 43, n. 11, p.2101-2108, nov, 2013.

[19] Lee JH. "Physicochemical and Sensory Characteristics of Sponge Cakes with Rubus coreanus Powder." Preventive Nutrition and Food Science. 20 (3) (2015) pp. 204-209.

[20] P. Fox, P. P. Smith, S. Sahi "Ultrasound measurements to monitor the specific gravity of food batters.” Journal of Food Engineering, 65 (3) (2004), pp. 317-324.

[21] S. Sahi, J. M. "AlavaFunctionality of emulsifiers in sponge cake production." Journal of the Science of Food and Agriculture, 83 (2003), pp. 1419-1429.

[22] M. Díaz-Ramírez, G. Calderón-Domínguez, M. GarcíaGaribay, J. Jim. "Effect of whey protein isolate addition on physical, structural and sensory properties of sponge cake." Food Hydrocolloids, Volume 61, December 2016, Pages 633639 .

[23] T. H. Emaga, R. H. Andrianaivo, B. Wathelet, J. T. Tchango, M. Paquot. "Effects of the stage of maturation and varieties on the chemical composition of banana and plantain peels." Food Chemistry, 103 (2007), pp. 590-600.

[24] P. Zhang, R. L. Whistler, J. N. BeMiller, B. R. Hamaker. "Banana starch: production, physicochemical properties and digestibility - a review." Carbohydrate Polymers, 59 (2005), pp. 443-458.

[25] Sivam AS, Sun-Waterhouse D, Quek S, Perera C. O. Properties of Bread Dough with Added Fiber Polysaccharides and Phenolic Antioxidants: A Review. Journal of Food Science. 2010.

[26] Ł. Sęczyk, M. Świeca, D. Dziki, A. Anders, U. Gawlik-Dziki. "Antioxidant, nutritional and functional characteristics of wheat bread enriched with ground flaxseed hulls." Food Chemistry, Volume 214, 1 January 2017, Pages 32-38.

[27] Y. Phimolsiripol, A. Mukprasirt, R. Schoenlechner. Quality improvement of rice-based gluten-free bread using different dietary fibre fractions of rice bran. Journal of Cereal Science, 56 (2) (2012), pp. 389-395.
[28] D. Sabanis, D. Lebesi, C. Tzia. Effect of dietary fibre enrichment on selected properties of gluten-free breadLWT Food Science and Technology, 42 (8) (2009), pp. 1380-1389.

[29] M. Gómez, B. Oliete, C. M. Rosell, V. Pando, "Encarnación Fernán. Studies on cake quality made of wheat-chickpea flour blends", LWT - Food Science and Technology, 41 (9) (2008) pp. 1701-1709.

[30] M. H. F. Felisberto, A. L. Wahanik, C. R. Gomes. "Use of chia (Salvia hispanica L.) mucilage gel to reduce fat in pound cakes". LWT- Food and Technology, 63 (1) (2015), pp. 1049$1055,2015$.

[31] A. Dadkhah, M. Hashemiravan, M. Seyedain-Ardebili. "Effect of shortening replacement with nutrim oat bran on chemical and physical properties of shortened cakes." Annals of Biological Research, 3 (6) (2012), pp. 2682-2687.

[32] C. Segundo, L. Román, M. Gómez, M. M. Martínez. "Mechanically fractionated flour isolated from green bananas (M. cavendishii var. nanica) as a tool to increase the dietary fiber and phytochemical bioactivity of layer and sponge cakes" Food Chemistry, 219 (15) (2017), pp. 240-248.

[33] D. Papasidero, F. Manenti, S. Pierucci. "Bread baking modeling: Coupling heat transfer and weight loss by the introduction of an explicit vaporization term". Journal of Food Engineering, (147) (2015), pp. 79-88.

[34] L. Campbell, S. R. Euston, Mohamed A. Ahmed. "Effect of addition of thermally modified cowpea protein on sensory acceptability and textural properties of wheat bread and sponge cake.” Food Chemistry, Volume 194, 1 March 2016, Pages 1230-1237.

[35] P. L. Pizarro, E. L. Almeida, N. C. Sammán, Y. K. Chang. "Evaluation of whole chia (Salvia hispanica L.) flour and hydrogenated vegetable fat in pound cake". LWT - Food Science and Technology, Volume 54, Issue 1, November 2013, Pages 73-79.

[36] A. R. Handleman, J. F. Conn, J. W. Lyons. "Bubble mechanics in thick foams and their effects on cake quality" Cereal Chemistry, 38 (1961), pp. 294-305.

[37] J. A. Delcour, R. C. Hoseney. "Principles of cereal science and technology" (3rd ed.), AACC International, St. Paul, MN, USA (2010).

[38] E. Wilderjans, A. Luyts, K. Brijs, J. A. Delcour. "Ingredient functionality in batter type cake making" Trends in Food Science \& Technology, Volume 30, Issue 1, March 2013, Pages 6-15. 